\title{
THE POTENTIALS OF RURAL TOURISM IN DEVELOPING RURAL AREAS IN ALBANIA
}

\author{
Henrietta NAGY ${ }^{\mathrm{a}}$, József KÁPOSZTA ${ }^{\mathrm{b}}$, Bledar META ${ }^{\mathrm{c}}$ \\ ${ }^{a}$ Szent István University, 2100 Gödöllö, 1 Páter K. str., Hungary, nagy.henrietta@gtk.szie.hu \\ ${ }^{\mathrm{b}}$ Szent István University, 2100 Gödöllő, 1 Páter K. str., Hungary, kaposzta.jozsef@gtk.szie.hu \\ c Szent István University, 2100 Gödöllö, 1 Páter K. str., Hungary, metabledar@yahoo.com
}

Cite this article: Nagy, H., Káposzta, J., Meta, B. (2017). The potentials of rural tourism in developing rural areas in Albania, Deturope 9(3):188-206.

\begin{abstract}
The inspiration that drove us to this study is that conventional tourism in Albania is focused more on promoting seaside, cultural tourism, luxury resorts, etc. which has demonstrated a good trend. At the same time, specific parts of the country have been abandoned due to their underdeveloped situation. Given their assets as constructed and indigenous habitat, they progressively appear as regions for rural tourism development. It could provide good development opportunities in remote mountainous areas that every day more are abandoned by the population because they do not have enough employment opportunities. But as for other rural areas which have a great potential for development of rural tourism, they are not preferred by the population either to live because they do not have developed agriculture. They do not provide the opportunity to earn enough money to live on at the appropriate standard. So the development of rural tourism would help the population in such areas to diversify their activities and earn some extra income, motivating inhabitants to stay in their own areas. Overall, it would contribute to the balanced development of the regions of Albania.
\end{abstract}

Keywords: regional development, rural areas, tourism, rural tourism, Albania

\section{INTRODUCTION}

Albania has very favourable conditions for tourism, including rural and agrotourism. It is located in the Southeast part of Europe and Southwestern of Balkan Peninsula (Fig. 1). Albania is a small European country covering a territory of around 28,700 square kilometers with a population nearly three million people. Boundary of Albania is $1094 \mathrm{~km}$ long altogether, out of which $316 \mathrm{~km}$-border along the sea, a $73 \mathrm{~km}$-long lake border, $48 \mathrm{~km}$-long river banks border and $657 \mathrm{~km}$-long terrestrial border. It is in the border with Montenegro to the North, with Kosovo to the Northeast, with Macedonia to the East and with Greece to the South. In the West and Southwest, Albania is bordering on the Mediterranean Sea. Albania shares the Adriatic Sea with Italy to the Western part and to the Southwestern part it shares the Ionian Sea with Greece. Most of the territory of Albania is a mountainous place, with Mediterranean climate where temperatures reach very high values in summer and very low in winter. 
Figure 1 Map of Albania

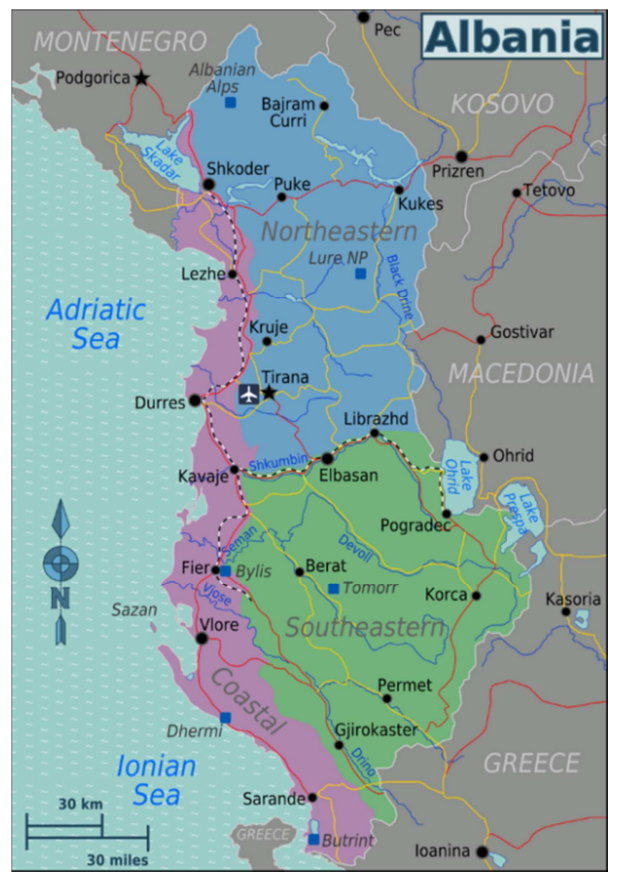

Source: https://en.wikivoyage.org/wiki/Albania\#/media/File:Albania_Regions_map.png

Albania is divided into three major regions as follows:

Coastal Albania: the long narrow strip between about 10 and $30 \mathrm{~km}$ wide along the whole Albanian coast, bordering both the Adriatic Sea and Ionian Sea

Northeastern Albania: the inland region to the North of the Shkumbin River, bordering Montenegro, Kosovo and Macedonia

Southeastern Albania: the inland region to the South of the Shkumbin River bordering Macedonia and Greece, and including the great border lakes, Lake Ohrid and Lake Prespa (https://en.wikipedia.org/wiki/Albania).

Based on the favourable conditions for tourism in general, including rural tourism, the Albanian government has started to advance rural tourism so as to manage nearby economies and to improve work and development opportunities. Rural tourism is viewed as a new component of the Albanian supply of tourism, providing opportunities for little villages and rural regions of the country as mountains, hills, rivers, lakes, farms etc. In this study we intended to collect information on rural tourism, to review tourism attempts and strategies, to give an overview on the current situation through analyzing two interviews in two case studies. Based on the favourable conditions for tourism in general, including rural tourism, the Albanian government has started to advance rural tourism so as to manage nearby economies and to improve work and development opportunities. Rural tourism is viewed as a new component of the Albanian supply of tourism, providing opportunities for little villages and 
Nagy, H., Káposzta, J., Meta, B.

rural regions of the country as mountains, hills, rivers, lakes, farms etc. In this study we intended to collect information on rural tourism, to review tourism attempts and strategies, to give an overview on the current situation through analyzing two interviews in two case studies.

\section{LITERATURE REVIEW}

In Albania there are two nationwide strategies that are to be implemented until 2020 with the aim to develop rural areas directly and indirectly. One of them is the National Strategy for Development and Integration 2015-2020, including a subchapter about regional development mentioning that the main challenge is to ensure a balanced development between regions of the country, and to increase the cohesion of the country's development in relation to other EU countries, through the consolidation of an effective system of regional planning and development. Specifically:

- Uneven development between regions of the country and in the international context. Development between regions of the country, between the municipalities and communes, but also between rural and urban areas, as well as between peripheral coastal and mountainous areas of the country remain uneven. Migration both within and outside the country is still a critical issue. There is an overpopulation in developed areas and depopulation of some areas, leading to inefficient use of infrastructure and services (schools, health centers, roads, water supply, etc.).

- Incomplete policy framework and capacity constraints. The policy framework should be consolidated, and the capacities for regional development management should be further developed. Powers of the regions regarding regional development management remain limited. The relationship between different levels of strategic planning and implementation at national, regional and local level remains weak. Project management capabilities in regional administrations remain limited.

According to the content in the agriculture and rural development subchapter of the abovementioned strategy, the challenges in this sector include:

- enhance competitiveness of agriculture and agro-processing in national, regional and global markets;

- enhance farm size through land consolidation and land market development;

- improve the technology and innovation transfer system through extension services;

- further improve infrastructure in agriculture towards sustainable use and management of natural resources and mitigation of climate change; 
- improve basic and recreational services, and diversify the activities that generate income in rural areas.

As for tourism development, as a result of infrastructure investment and improved service quality, the tourism sector share in the economy has grown considerably in recent years. Direct contribution of the travel and tourism sector in GDP in 2016 stood at $8.4 \%$ (is forecasted to increase by $5.2 \%$ by 2017 ), while total contribution to GDP in economy was at $26 \%$ (is expected to rise by $5.3 \%$ by 2017 ). Tourism in 2016 supported directly 85,500 jobs or $7.7 \%$ of total employment and indirectly 267,000 jobs or $23.9 \%$. Visitor exports generated $56.1 \%$ of total exports in 2016 (https://www.wttc.org/-/media/files/reports/economic-impactresearch/countries-2017/albania2017.pdf).

Challenges in tourism sector include: improve the image of tourism through enhanced promotion and marketing; perfect the certification system and standards in order to increase the quality, as well as human capacity building to improve tourism services; improve the climate business and encourage private investment; organise data collection and analysis at local, regional and national level according to international standards.

According to the strategic plan, the priorities and objectives of the sector are as follows:

\section{Develop the tourism sector by increasing:}

- Direct contribution to GDP by $0.2 \%$ annually; contribution to total employment from $19.7 \%$ in 2011 to $20.3 \%$ in 2020 ; and the number of non-resident foreign nationals by $50 \%$ compared to 2011 .

- Promotion and marketing to improve Albania's tourism image as a tourist destination of special interest, through: participation in international fairs, distribution of promotional materials, online promotion, development and transmission of TV spots;

- Establishment of tourism promotion offices that promote tourist values and resources in the international markets targeted for attracting foreign tourists.

2. Diversify tourism products extended in the whole territory to ensure integrated tourism development:

- Expand the season beyond the actual 3-month period;

- Upgrade infrastructure and access to objects classified as cultural monuments in order to double the number of visitors;

- Establish a National Register of tourist resources and create new tourist routes in rural areas rich in natural and cultural resources

- Support the creation of tourist destination management organizations with the involvement of public stakeholders, business and tourism community. 
Nagy, H., Káposzta, J., Meta, B.

3. Perfect the system of certification and standards in tourism in order to increase the quality and strengthen data collection and processing capacity:

- Strengthen human capacity in the tourism sector through: promotion and certification of professional training courses in colleges and universities, award of national prizes or success/excellence awards in tourism services; Train employees in tourist service offices in 9 regions and sea entry points on the tourist data processing standards of the World Tourism Organisation;

- Train tourist operators in at least 4 regions regarding the collection, processing and entry of tourism data, in collaboration with the Tourist Service office.

The other relevant national strategy is the Strategy of Tourism Development in Albania 2014-2020 that aims to promote the sector in the country. According to the strategic direction of nature and rural tourism 2014-2020, in selected destinations with attractive potential natural and traditional villages with an authentic lifestyle there is an attractive tourist product range of special interest. Offers in tourism and rural nature are well-known and consolidated in the main markets of resources.

\section{Economic objectives}

- Increase the contribution of nature and rural tourism in income and economic impact;

- The nature and rural tourism contributes to poverty reduction and revenue growth in different destinations of the country.

2. The objectives regarding market

- Nature and rural tourism is an integral part of the offer cultural and natural tourism to foreign tourists (increase (triple) the number of international tour operators that offer nature-based tourism);

- Tourism nature, especially natural active tourism, an increased number of domestic tourists.

3. Strategic measures to create product of nature and rural tourism, institutions, planning, standards

- Determination of functional responsibilities at the national level for nature and rural tourism;

- The destination management support to 10 destinations for natural and rural tourism;

- Support for marketing development of natural and rural tourism destination.

\section{Environment and attractive atmosphere to destinations}

- Supporting environmental improvement and attractive atmosphere in the natural and rural tourism destinations;

- Accommodation support in villages. 
Nagy, H., Káposzta, J., Meta, B.

\section{Access}

- Support the planning and realization of a signaling system to inform and guide tourists;

- Support improved ease of entry in natural and rural destinations and transportation within the areas.

\section{Business support services}

- Support the establishment of advisory services and support to businesses

\section{Support for the organization of supply and activities}

- Support the development of rural tourism;

$>$ Support traditional local activities,

$>$ Support traditional farms,

$>$ Support the creation of agro-biodiversity products related to tourism,

$>$ Intertwined support for rural development projects.

- Supporting the tourism product creation to travel on foot (hiking);

- Support the creation of tourism cycling in mountains;

- Support measures for the creation of the offer for tourism in natural parks;

- Support measures for the development of winter tourism;

- $\quad$ Supporting the development of rafting as a tourist offer;

- Support the creation of mountaineering as tourist offer;

- Creating tourist offer of the special nature for sport: (flying with parachute gliding, fishing as a sport, etc.);

- The creation and implementation of security standards for each natural and rural subproduct;

- Measures to ensure and improve the quality of bids for natural and rural tourism.

\section{Support for investment}

- Pilot center a resting place for skiing;

- The combined measures.

Regarding the abovementioned strategies, their aim is to sustain and develop sustainable agriculture and rural tourism, to develop necessary infrastructure as well as to widen the supply of tourism services. Reviewing the above strategies gives us the opportunity to see the government's approach towards the development of these two sectors parallel.

Many studies have different definitions of referring to tourism activity taking place in rural areas; some of these definitions qualify as agro-tourism, soft tourism, alternative tourism, 
farm tourism, etc. But in several countries these definitions have different meanings. The term rural tourism is adopted by the European Union, and refers to all tourism activities that take place in a rural area (Hall and Page, 2002).

Another definition of rural tourism can be as an experience in a given country or area with a variety of attractions in agricultural areas in which developed specific activities which are not developed in urban areas. Involved in wide space is an essential feature of this type of tourism, where development is at low levels compared to urban areas. In this way, visitors can experience the agricultural or natural environments directly. To create a clearer idea of rural tourism should be characterized by (Lane, 1994):

- Should be taken place in rural areas;

- Rural should be working - to have space, to have contact with nature, to have respected traditions and habits, enterprises should be small-scale which is also characteristic of rural areas;

- To be in rural level - as seen by the place where they live also the characteristic of style buildings;

- Traditional character that prevails, farming organically from families that reside there.

Rural tourism is interpreted in various ways by authors in different countries. For example in Italy, it covers all activities related to the countryside either it is a weekend spent in a hotel for 100 people or walking on a wine route. In the Netherlands, village tourism is rather a holiday in a camping next to a farm, in which the most popular activities are going on excursions, cycling and horse-riding (Turner, 1993). In Greece, e.g. the major service provided in rural tourism is „,bed and breakfast”, i.e. accommodation in traditionally furnished rooms and breakfast made from home-made traditional products. Additional services might be offered by restaurants; other cultural and recreational programs may also be available. In Finland, village tourism is rather the rent of a holiday home, usually without catering (Rátz \& Puczkó, 1998). In Hungary, there is no generally accepted definition for village tourism. It covers activities from the simple village accommodation to a complex product with multiple elements.

The definition by EURTER French Institute is broadly accepted and applied: rural tourism is defined by the valorisation through tourism of agrarian spaces, natural resources, cultural heritage, rural housing, local popular traditions and products through specially labelled products that reflect the regional identities and cover the needs of the consumer for accommodation, gastronomy, leisure activities, animation, and other services, with the 
objective of a local sustainable development and an adequate answer to the needs of leisure of the modern society within a new social solidarity between city and countryside.

If we look at it as a whole, rural tourism is considered to be a sustainable, multi-functional activity based on local resources and related traditional agricultural, cultural and natural resources (OECD, 1994; EC, 2000; UNWTO, 2002). It is noteworthy that tourism is in many cases an additional activity that provides significant support to the traditional rural economy, made up primarily of agriculture, forestry, crafts and other activities (Moric, 2013).

New forms of tourism, such as rural tourism, with all its types and varieties, require many micro and small-scale businesses, family-owned, dispersed and located in rural areas. In this way the economic effects of tourism rest and spread inside the local community, the multiplier is increased, and leakages of tourism income are decreased compared to other types of tourism destinations. Rural tourism obviously generates new employment opportunities and helps to sustain the existing business and creates the new ones. Hence, the key role of rural tourism in rural development may be seen in diversification of economic activities and income in rural regions. Apart from this, protection and preservation of cultural heritage in rural areas, better opportunities for women and disabled people, protection of the environment and biodiversity, etc. are very important (Moric, 2013).

Based on the abovementioned it can be stated that rural tourism is related to rural areas, mainly dominated by agricultural activity that are usually considered underdeveloped regions (Bujdosó, Dávid, Wéber, and Tenk, 2015). Albania has various attractions in rural areas, which give to visitors and tourists different emotions and feelings. Since the territory of the country is unique, tourists and visitors can find there a mix of attractions from the high mountains at $2764 \mathrm{~m}$ (Korab's mountain) to the sea level, beautiful mountains, hills, rivers, lakes, waterfalls, canyons, and more and more natural attractions.

Therefore, exploring the potentials of rural tourism in countries with rich natural and cultural heritage and with unfavourable economic and social conditions is really important and inevitable in sustainable and long-term economic development.

\section{OBJECTIVES AND METHODS}

Our aim was to explore the current situation of rural tourism in Albania and to discover the challenges and the possibilities. To achieve the purposes of this study we used primary and secondary data. As for primary research, two interviews have been conducted for two case 
Nagy, H., Káposzta, J., Meta, B.

studies. One case study is about "Uka" farm, which is located about $10 \mathrm{kms}$ away from Tirana in the central area. The target of the other case study was "Farma Sotira" located in the country's Southeast zone. Both businesses are considered successful in rural tourism, though they have different farm size. Uka farm operates successfully only on 2 hectares of land, while Farma Sotira is a mixed farm that offers various services in the field the rural tourism and operates in a one land area of more than 10 hectares. They prove that success is not in direct relation with farm size in rural tourism.

In addition to the interviews, information has been received from a questionnaire survey, containing 21 questions, sent to 25 businesses operating in the field of rural tourism. This has been done to get information about the entities operating in this field, in order to obtain information about the problems that they face every day, to see whether they offer services in competent professional way, if they have the proper training regarding rural tourism, if they operate based on tourism, agriculture and rural policy of the country. The questionnaires were completed anonymously by the businessmen, which were selected in different areas of the country (in the Northern, Central and in the Southern part) to get an overall information throughout the country. The questionnaires were completed in February-March 2017, while interviews and visits to the two farms operating in the field of rural tourism were done in August 2016. Secondary data was obtained from the Institute of Statistics of Republic of Albania, Ministry of Agriculture and Ministry of Tourism to support the results obtained from interviews and questionnaires. In this paper we intended to primarily focus on the results and conclusions of the interviews not detailing with the secondary and questionnaire data much. However, in order to see the increasingly important role of tourism in Albania, some national statistics need to be shown, though statistics about rural tourism are not available. That is why it was necessary to use primary data for rural tourism. As it is seen on Fig. 2., there has been a sharp increase in the number of foreign citizens over the last 15 years from 317.000 to 4.131.000. 
Figure 2 Arrivals of foreign citizens to Albania, 2000-2015

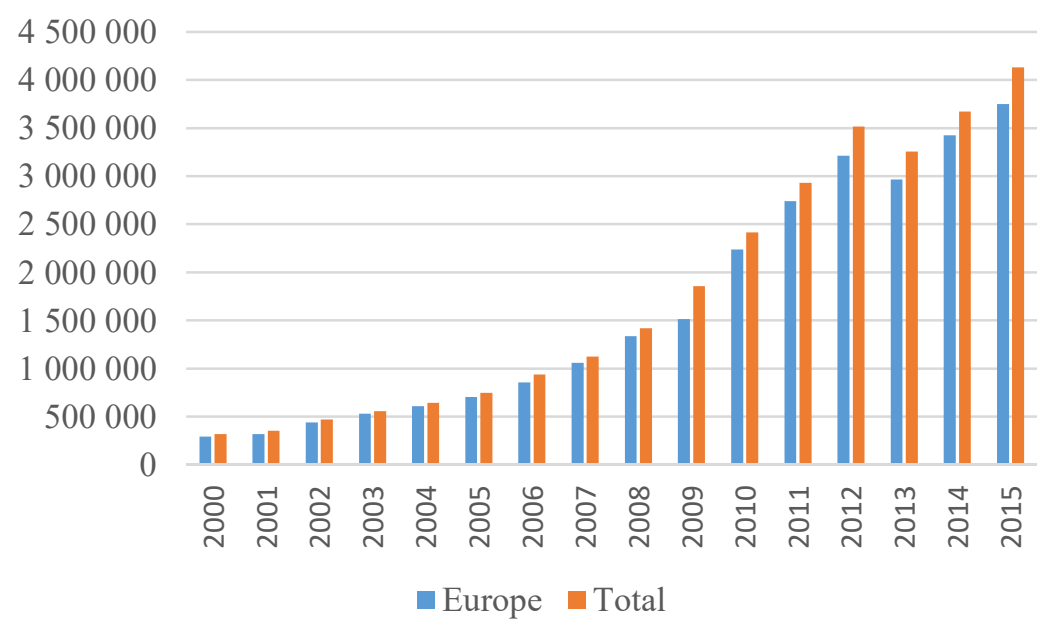

Source: http://www.instat.gov.al/en/Home.aspx

If we look at the numbers regarding the arrivals to the country and the data about the arrivals in hotels (Fig. 3), we can see that only approx. 10\% of the total arrivals stayed in hotels in 2015, while the rate in 2000 was nearly 50\%. It means that alternative accommodations, e.g. rural accommodations have been getting more and more importance.

Figure 3 Arrivals of foreigners and Albanians in hotels (in thousand), 2000-2015

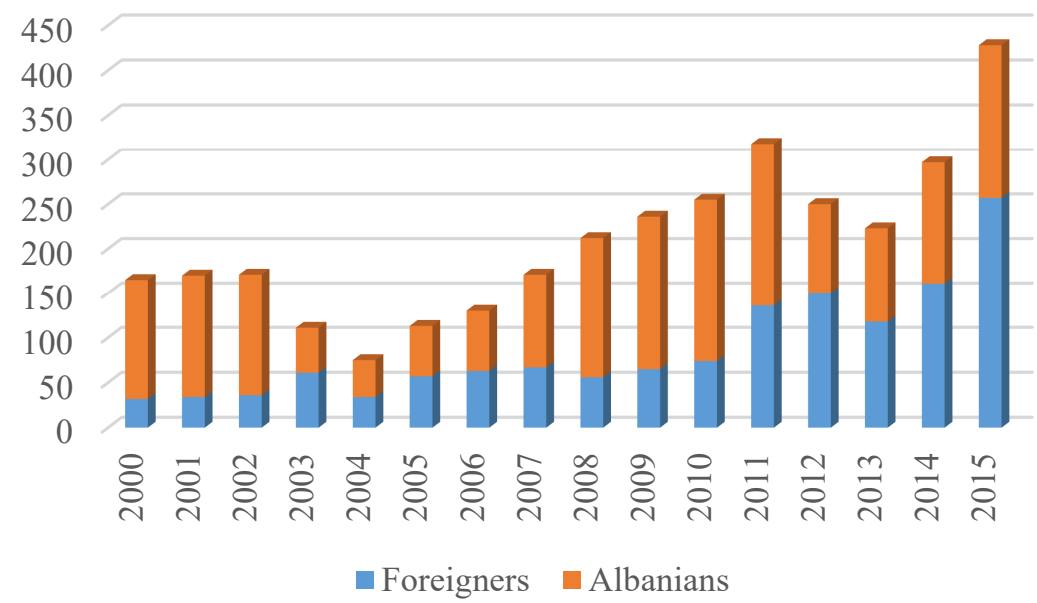

Source: http://www.instat.gov.al/en/Home.aspx

It is really interesting to compare the data of Fig. 3 to Fig. 4, because it shows the number of beds in hotels increasing over the years. While in 2000 there were nearly 6,000 hotels bed, in 2015 there were almost 16,000. However, this figure can be considered still insufficient to receive the total number of tourists. 
Figure 4 Number of hotel beds in Albania, 2000-2015

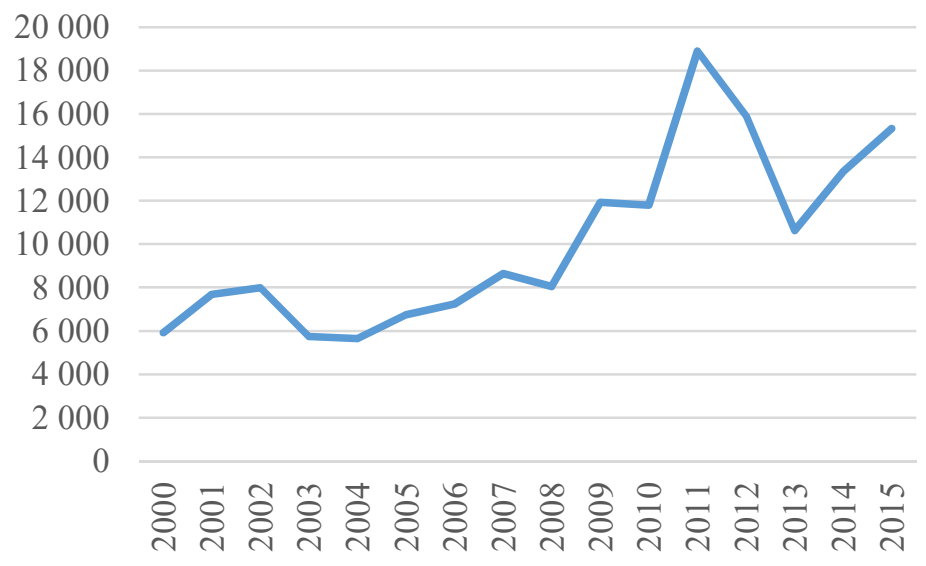

Source: http://www.instat.gov.al/en/Home.aspx

\section{RESULTS AND DISCUSSION}

\section{Introduction of "Uka Farm"}

"Uka Farm" started to be built in 1996. It is considered a multicultural farm; the farm lies on an area of about two hectares of land and is located in the village of Laknas in Tirana district (Fig. 5).

Figure 5 Uka Farm

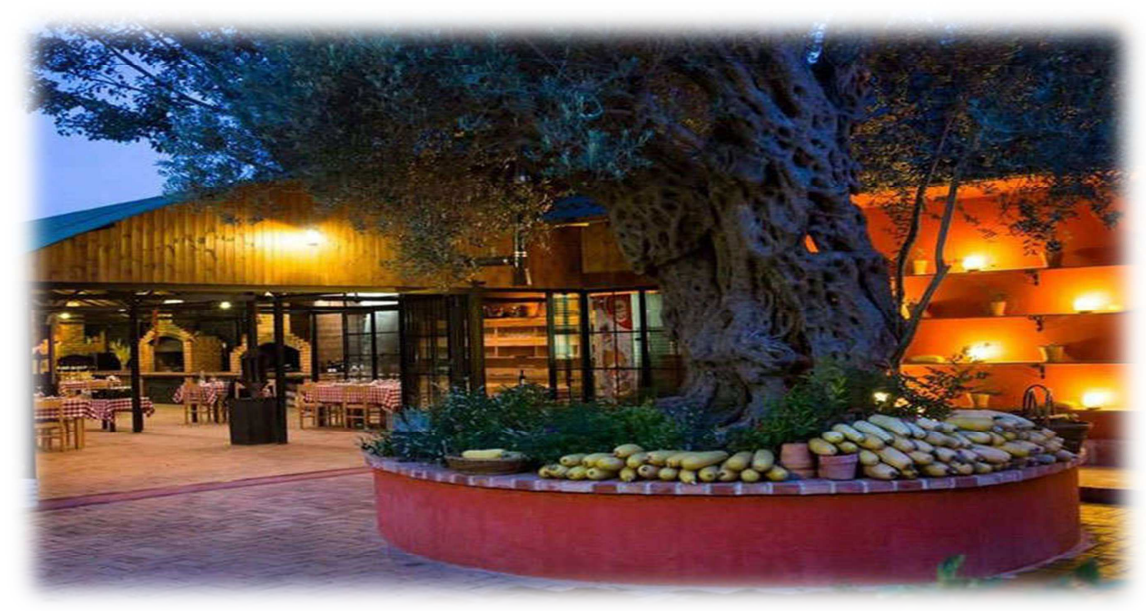

Source: Bledar Meta's own photo, 2016.

The owner did not take other land by rent, everything is operated on two hectares. There are about 30-40 different cultures - e.g. apples, peaches, pears, plums, cherries, citrus and olive groves etc. even kiwi. The farm also produces many different vegetables. The farm has been created because of scientific purpose and research and from the passion of the owner, who is a professor at the Agricultural University of Tirana, to offer to the students valuable practical 
content in their studies and a place where students can work on their thesis in areas related to agriculture and arboriculture. Somehow this farm is a natural vegetation laboratory and an ecological habitat where different birds and various insects can live. Dr. Professor Rexhep Uka has started to build this farm for his own study in entomology and plant protection, with the main goal to attract as many as insects as possible to the farm, to study biological war between insects and produce organic products in natural growth, without using pesticides.

From the standpoint of this farm, the real business operation started a few years later, when a winery was built at the end of the farm. The good performance of the winery (from both qualitative and financial point of view) has motivated the owner to build also a restaurant on the farm. Thus, by the construction of winery and the restaurant, the farm has become complete and it was a pretty lucrative business. The scientific purpose of the farm was very interesting, however, farms with only this purpose are not preferred by many visitors and tourists. The few tourists who visited the farm arrived with scientific purpose but it was not enough to derive sufficient profits. The farm at this time was financed by salaries of members of the family. In the beginning, the wine production has been export-oriented and also sold on the domestic market. But when one of the sons of the owner Flori, completed his master studies in Italy for Oenology, together they decided to build the restaurant in 2014, where they can sell wine and other products produced on the farm. In this way they will earn more and will have the possibility to offer not only relaxing natural environment on the farm, but also organic products produced on the farm, cooked and served in professional way to visitors and tourists. Visitors and tourists visiting Uka Farm are various, both foreign and domestic tourists and guests. Uka farm has been also booked for various family celebrations, business lunches and dinners, birthdays etc. The environment created on the farm is very relaxing for all age groups from all children to the elderly. Visitors and domestic tourists are mainly from Tirana and surrounding areas because it is in a short distance, about $10 \mathrm{kms}$ from Tirana, but they also come from other parts of Albania. Many tourist agencies orient foreign tourists to visit Uka Farm to enjoy traditional Albanian dishes, wonderful and quality wine, which are produced from organic products grown on the farm and in the surrounding area. During weekends the farm is mainly frequented by families who come with their children to rest, to enjoy cthe cuisine and to relax in the green nature. Products that are served are mainly those which are produced on the farm because the farm operates with the concept "from farm to table", but it is unable to produce all its own products.

The farm cooperates with local farmers and buy their products that are cooked and served in the farm restaurant. Most of these products also grown organically. In this way the farm serves as a selling point for products from the local farmers, helping them earn some extra 
Nagy, H., Káposzta, J., Meta, B.

income without spending more money on their transport. Regarding financing the costs of the farm, it has been rather private funding in cooperation with banks by taking loans from them, but also with some support from the government. Flori, the son, mentioned that the farm has benefited from government funds only to inconsiderable extent. He also expressed concern about bureaucratic access to benefit from government subsidies, so he believes that it is worth to obtain loans from banks than lose a lot of time and energy to benefit from small amount subsidies. Flori also stated that if the government eased the bureaucracies and shortened the time spent to apply for subsidies, it would indeed be a very big help for such businesses. It would be a strong motivation to work more, to expand further their farm and to make things of better quality in the future. On the farm including the restaurant 20 people were employed full-time in different professions according to business needs until 2016.

Regarding the goals for the future, the owners do not wish to change many things because they want to remain loyal to organic production on the farm with zero use of pesticides. The only thing they can make compromise in it is to increase further the quality of organic products through scientific research on the farm. They plan to invest more in the direction of tourism, building small wooden villas which can also offer accommodation for tourists and different visitors. Dr. Professor Rexhep Uka and his sons plan to build a private agricultural university next to the farm where the farm will serve as a laboratory and scientific research center. Flori said that this plan could be realized if they were able to find sufficient financial support. It shows that if the government supports them in this direction, which would be a very big support for them, they would build the first private Agricultural University in Albania. They have the experience in this regard, they have energy, passion and very strong motivation, things that will direct them to a secure success.

\section{Introduction of "Farma Sotira"}

Farma Sotira is located between Erseka and Leskovik towns in a valley called Sotire, which extends beneath the mountains of Omit, Pogonica and Çuka. Farma Sotira was built in 1998. Its owner, Elton Hida, immigrated to Greece before 1998. When he returned, he decided to create a fishpond to grow trout fish because in that area there is clean water and abundant. To build such a business he signed a contract with the local government to take the area for rent because the area was owned by the state. Then he started to work on the systematization of the area and surrounding waters because the conditions were not suitable to start building this business; it needed prior adjustment. After the area disposition, he began the construction of rainbow trout fishponds because these waters were suitable for this kind of trout due to their 
cold temperature. So he ranked 4-5 among the first businesses in growing trout in Albania. $\mathrm{He}$ indicated that this kind of business at that time was very profitable. He got large profit from it because the competition was very small compared with the ever-growing demand of trout meat.

Figure 6 Farma Sotira

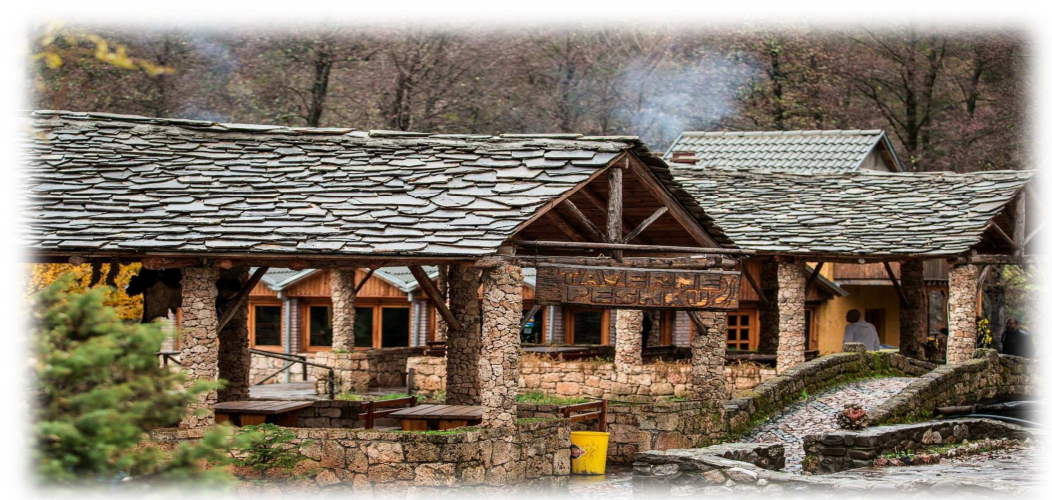

Source: Bledar Meta's own photo, 2016.

After some time, the area began to be recognized by visitors as the fish farm. Main buyers of trout were from the city of Korca, which is located $80 \mathrm{kms}$ from the farm and the surrounding areas. Clients who came to buy and eat cooked fish recommended the owner to build rooms to accommodate them and other visitors, since the area was in the mountains and they could stay there all the day to relax, enjoy the cooked trout in the traditional way. So the owner started to build several small wooden houses. Elton, the owner of the farm, showed that he was always a step back in comparison with the number of tourists and visitors in meeting their requirements.

Stunning nature and environment, very calm and safe place, brought to the farm even more tourists and visitors from different foreign countries of the world, but mainly German and French tourists. Foreign tourists began arriving even though they had not yet offered accommodation so they use their recreational vehicle to sleep on the farm. It shows that tourists are very surprised with the quiet environment, stunning views, and traditional food which are cooked in a tradition way - mainly from organic farm products. Noting that the number of domestic and foreign tourists has increased more and more, the owner decided to invest more to make that area reflecting the appearance of a more attractive tourist destination.

Until August 2016, there were about 300 sheep, 130 cows of different breeds that suit mountainous terrain and about 80-90 calves. All cows left in free-grazing in the natural environment of the farm and no additional food is given. Calves usually go on sale or slaughter for meat in different areas of the country and also for tourists meat served. Farma 
Sotira is a mixed farm, because cows, bred goats, rabbits, pigs, chickens, ducks \& gooses, bees, horses can be found there. There are several cultivated vegetables on the farm such as tomatoes, peppers, beans, cabbage, garlic, eggplants, okra, potatoes, and many other vegetables that fit the climate zone. Fruits like grapes which are used to make wine, rakia, juice, jam, etc., as well as other fruits like apples, pears, plums, walnuts, chestnuts, cherry etc. are also produced. In addition, there are also wild fruits such as nuts, wild strawberries, wild blackberries, cornelian, wild blueberries etc. All of these cooked in the traditional way to be served to tourists.

Farma Sotira has 5 wood cabins for families and 5 small wood cabins for single person or couple. Also on the farm is the restaurant with a capacity about 30-40 people at the same time, but in its exterior environment can be served on wooden tables with wooden umbrellas that offer a convenience and a comfort in nature. Farma Sotira also offers open pools during the summer period, entertainment places for children, different games in nature, such as volleyball, soccer etc. Elton indicates that when tourists come they are very surprised by the nature that offer surrounding mountains and ask them in order to do guides in the mountains and doing hiking, others prefer to take their bike and cycling along the motorway that connects town of Erseka with Leskovik and enjoying the wonderful nature that offers areas along the way (Fig. 7). To entertain tourist, farm cooperates with folklore groups of the area, offering music, song and traditional dance of the region where it is located. The special traditional dishes, cooked in the traditional way are another added value of Farma Sotira, because the feedback they got from tourists is they are very satisfied so they wish to return to visit the farm again. If the tourists want to catch the fish in fishponds by themselves which they want to consume, it is also possible. Camping, hiking, swimming, horse riding, fishing, and barbecue, cycling, and hunting are also offered on the farm and its surroundings.

Figure 7 The location of Farma Sotira

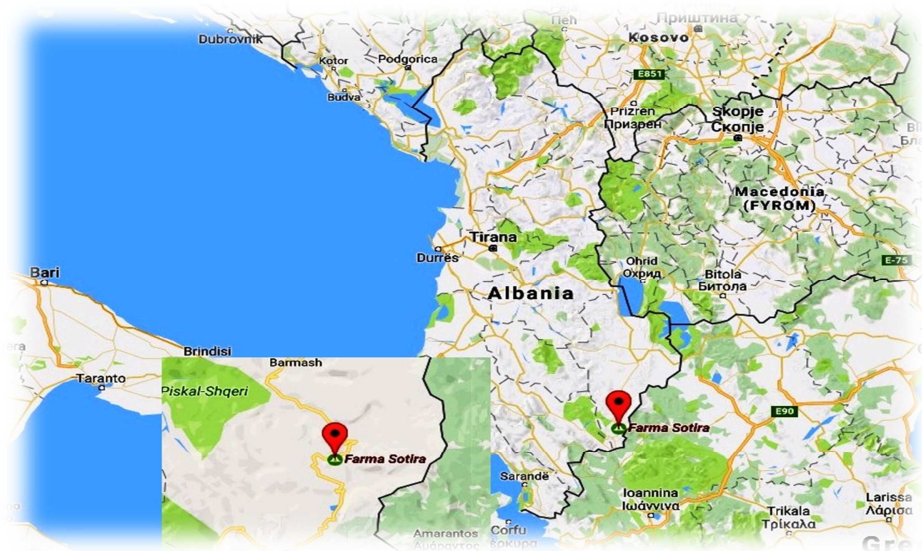

Source: https://www.google.hu/maps 
Nagy, H., Káposzta, J., Meta, B.

The farm lies on a territory of about 10 hectares but the surrounding areas and mountains are rented from the state or the owners and used by the owner of the farm. The farm also offers participation in different processing works on the farm for tourists who are interested and can get discount from accommodation cost in return. The owner of the farm said that the restaurant and tourism activities of the farm contribute a lot to the farm income and he thinks that step by step they wish to invest more in this direction.

The farm has been financed mostly from personal finances in combination with bank loans. Regarding government support, he said that they have not had adequate support and benefited little from such support. The many bureaucracies and criteria that are set by the government to benefit from various grants or subsidies shall make him almost impossible to be the beneficiary of those funds. According to the owner, if the government would support him through various grants and subsidies, it would be really good support and strong motivation for him and his family to increase the capacity and quality of services and products that the farm offers.

\section{CONCLUSION}

Albania is a small country but has variety of resources. The presence of these resources makes the country to have great potential for its further development. Thus tourism sector provides increasingly important contribution to the country's economy. Statistics clearly show that the number of tourists sharply increased over the last 15 years. As Albania has a variety of natural resources ranging from the Alps in the North to the Ionian Sea coast in the South of the country, it has a great potential to develop tourism further focusing on rural tourism.

Based on the interviews, based on the analysis of the answers, obtained from questionnaires and statistical data we should state that the current situation of rural tourism is quite weak, and in its infancy. Entities that currently offer rural tourism face many problems of different natures. The rural tourism development and its support by the government will give a very positive effect on the development of rural areas but also beyond. The rural tourism development provides important contribution to the creation of new jobs, keeping jobs for the population and increases their interest to stay in that region and creates new business opportunities. Rural tourism also provides more opportunities for youth in rural areas and motivates them to stay and not leave the area to find the best opportunity of living in urban areas or abroad.

The community diversification, revitalization of social and cultural life in rural areas, and the revival of community pride, are also positively affected by the rural tourism development. 
So revitalization of life in general in rural areas is another positive effect that comes as a result of developing rural tourism. While also maintaining, culture and heritage in rural areas, traditional art and craft works. This means the creation of art secure market to sell local products without spending much money on transportation costs, maintenance and their preservation, but also increase the value of agricultural products, avoiding traders and giving farmers a source of significant farm income. Preservation and improvement of environment, preservation of natural landscapes and historical sites will be additional importan benefits of the rural tourism development. Community involvement in rural tourism makes it a successful sector, giving a positive impact on product development to grow up infrastructure, and activities. The success of rural tourism lies in the regions' quality growth, their ethics, growing partnership, establishment of centers for visitors and cultural heritage, increase funding in rural areas which up to this day is at low levels. All of the above may result in higher economic benefits in rural areas but not only. Increased contribution in GDP of tourism in general and rural tourism in particular, more employment, more prosperity in rural areas, contribution to the development of agriculture are all expected outcomes.

During the analysis of the responses from questionnaires and interviews, we noticed several problems that entities operating in the rural tourism sector face. The poor road infrastructure in rural areas makes the development of agriculture and rural tourism stumble. Poor financing from banks to agriculture as well as the strit requirements mean other challenges for agriculture and rural tourism. Information about state strategies for agriculture and tourism, laws and rules that are in effect for these sectors do not really have strong relation with the practice in rural areas. This has led to a private initiative that deals with the development of rural tourism, sometimes not complying with the national strategies and sometimes not supported by the government. Education and training in the rural tourism sector - to be familiar with the best practices of this sector - is also at very low levels, with the exception of some subjects which are trained by international institutions that operate some small scale projects in this sector. Another problem that was mentioned by both famers in the interview is the complicated procedure to benefit from state subsidies or grants, the long time it takes to receive these funds, and the numerous bureaucracies that exist for fund generation to benefit in question.

On the basis of the analysis conducted we can list up some solutions for the existing problems. First, the support of sustainable agriculture and diversification could motivate farmers to expand their activites and link the agricultural production with rural tourism (as it was proven by two different farms in the interviewing). Second, the two sectors must be 
supported by different state funds - not to increase production but to achieve integrated development in the rural areas based on the rich natural resources. This would promote quality products and services in both sectors and will make them more sustainable. The simplification of the application process is also inevitable. Third, the extension service and relevant institutions should be more active, in terms of giving information related to rural tourism and training. This would bring an awareness of farmers and the rural population about economic importance and opportunities that come from the rural tourism development. Based on the results of the survey, farmers would be really interested in such trainings, so the demand for getting more knowledge is really high. It would be recommended to set up training centers for rural tourism with low cost or relevant government institutions could provide such trainings directly on the field. This would help to educate farmers and the rural population better understanding the importance of this sector and stimulate them to develop it. Fourth, investing in road infrastructure in rural areas would make them easily accessible by visitors and tourists that would boost rural tourism development.

\section{SUMMARY}

In general terms, the national strategies detailed in the paper are important but not enough. The government and its institutions should play more active role to support and promote the development of rural tourism hand in hand with agriculture. If the various and valuable conditions are used properly, the sectors would contribute to the development of rural areas, to the economy as a whole, to the reduction of unemployment in rural areas, to curbing immigration. They would stop the depopulation of rural areas, increase the standard of living in rural areas, and have impact on the development of agriculture too. In such a way it could become simultaneously an additional source of farm income for those who would offer this kind of tourism, but also could create or boost local market for local traditional and organic products (as it was shown in the case studies). In addition to economic benefits, rural tourism also contribute to the development of society by developing human resource as well as the preservation of cultural values and promote environment-friendly approaches.

\section{REFERENCES}

Bujdosó, Z., Dávid, L., Wéber Z., \& Tenk, A. (2015). Utilization of Geoheritage in Tourism Development, Procedia - Social and behavioral sciences, Vol. 188

European Commission (2000). Towards quality rural tourism: Integrated Quality Management (IQM) of Rural Tourist Destinations, Brussels: Enterprise DirectorateGeneral Tourism Unit Hall, C. M. \& Page, S.J. (2002). The geography of tourism and recreation: environment, place and space, London Routledge

Lane, B. (1994). What is rural tourism?, Journal of sustainable tourism, Volume 2, No.7

Institute of Statistics of the Republic of Albania. Retrieved from http://www.instat.gov.al/en/Home.aspx

Map of Albania. Retrieved from https://www.google.hu/maps

OECD (1994) Tourism Strategies and Rural Development, General Distribution, OECD / GD (94) 49, 013927, Paris 
Moric, I. (2013). The Role and Challenges of Rural Tourism Development in Transition Countries: Montenegro Experiences, TURIZAM | Volume 17, Issue 2, 84-95

Rátz, T., \& Puczkó, L. (1998): Rural Tourism and Sustainable Development in Hungary. Paper presented in "Rural Tourism Management: Sustainable Options" Conference. September 9-12, 1998. The Scottish Agricultural College (SAC), Ayr, Scotland.

Regions of Albania. Retrieved from https://en.wikivoyage.org/wiki/Albania\#/media/ File:Albania_Regions_map.png

Republic of Albania, Council of Ministers (2013). National Strategy for Development and Integration, Retrieved from https://shtetiweb.org/wpcontent/uploads/2014/06/NSDI_2014-2020_version_JUne-2013.pdf

Smith, V., \& Eadington, W. (1992). Tourism alternatives, potentials and problems in the development of tourism, Wiley, Chichester

Turner, G. (1993): Tourism and the environment: the role of the seaside, Insights: A 125-31

UNWTO (2004). Rural Tourism in Europe: Experiences, Development and Perspectives, Madrid: UNWTO

World Bank (2002). "Rural Development Strategy for Albania", World Bank, November 2002,78

http://siteresources.worldbank.org/INTALBANIA/Resources/AlbaniaRuralStrategyAlba nian.pdf.

World Travel \& Tourism Council (2017). Travel \& Tourism Economic Impact 2017 Albania, Retrieved from https://www.wttc.org/-/media/files/reports/economic-impactresearch/countries-2017/albania2017.pdf 